\title{
Erratum to: Conditions for successful local resource management: lessons from a Brazilian small-scale trawling fishery
}

\author{
Thiago Zagonel Serafini ${ }^{1} \cdot$ Rodrigo Pereira Medeiros $^{2} \cdot$ José Milton Andriguetto-Filho $^{3}$
}

Published online: 1 September 2016

(c) Springer-Verlag Berlin Heidelberg 2016

\section{Erratum to: Reg Environ Change \\ DOI 10.1007/s10113-016-0990-7}

Unfortunately, the article was published without the acknowledgement section. The complete text is given here.

Acknowledgments We are thankful to the Coordenação de Aperfeiçoamento de Pessoal de Nível Superior (CAPES) for providing a postdoctoral scholarship to TZS (Edital CAPES/Ciências do Mar) linked to the project: "The Ocean Continent Interface in Estuarine and Coastal Regions: Structure, Processes, Management, and Sustainability". The authors are also thankful for the support and contributions of Dr. Paulo da Cunha Lana. This study was supported by the TransForMar Network (Rede Transdisciplinar em Cogestão Adaptativa para o Ecodesenvolvimento).

The online version of the original article can be found under doi:10.1007/s10113-016-0990-7.

\footnotetext{
Thiago Zagonel Serafini

thiago.serafini@unifesp.br

1 Universidade Federal de São Paulo, Santos, SP, Brazil

2 Universidade Federal do Paraná, Pontal do Paraná, PR, Brazil

3 Universidade Federal do Paraná, Curitiba, PR, Brazil
} 